\title{
First occurrence of Filinia longiseta (Ehrenberg, 1834) from low- orders streams in a protected area at Cerrado-Amazon boundary, central Brazil
}

\author{
C. Padovesi-Fonseca ${ }^{a *}$ \\ a'Universidade de Brasília - UnB, Departamento de Ecologia, Laboratório de Limnologia, Núcleo de Estudos Limnológicos \\ - NEL, Brasília, DF, Brasil \\ *e-mail: padovesif@gmail.com
}

Received: September 30, 2019 - Accepted: May 8, 2020 - Distributed: November 30, 2021

Headwaters originated in boundary areas naturally flow towards the basins, most of the time forming ecological corridors for many aquatic species. Based on the potential of the surveying the fauna in these connection areas to become an important strategy to reduce gaps related to geographical distribution of aquatic species, this study was developed in streams of a protected area in CerradoAmazon boundary.

This study was developed in the Parque Estadual da Serra de Ricardo Franco, Mato Grosso state, central Brazil (between parallels 14 ${ }^{\circ} 50^{\prime} 17.02^{\prime \prime}$ and 14 ${ }^{\circ} 55^{\prime} 34.00^{\prime \prime}$ $\mathrm{S}$; between meridians $60^{\circ} 1^{\prime} 9.98^{\prime \prime}$ and $60^{\circ} 11$ '35.02" W), on March 2014, in headwater streams of a protected area in Cerrado-Amazon boundary. The state Park, with an area of 158,620 ha, is located on the Brazilian Shield in a transition zone between the Amazonian rain forest and the dry forest and Cerrado savannas. In the uplands of the park the streams flow into the upper course of the Guaporé river, from Madeira river basin, Amazon. The cliffs of the serra de Ricardo Franco rise up $200 \mathrm{~m}$ tall and many locations have waterfalls. This study presents the first record of rotiferan Filinia longiseta (Ehrenberg, 1834).

Identification was based on Koste (1978) and Koste and Robertson (1983). Nomenclature and taxonomy were based by Segers (2007). Rotiferans were evaluated with a stereomicroscope at $25 \mathrm{x}$ magnification. Filinia longiseta specimens were measured at the longest part of the animal's body and two spines - the lateral and also the caudal seta were measured separately. Specimens were deposited in the Laboratory of Limnology at the University of Brasília (UnB-DF), Federal District, Brazil (sample CZ 0114).

Specimens dimensions: Body length: $177 \pm 3 \mu \mathrm{m}$; Lateral setae length: $520 \pm 15 \mu \mathrm{m}$; caudal setae length: $300 \pm 8 \mu \mathrm{m}$. Type of habitat: low-order streams.

Filinia longiseta has a broad distribution, including Paleartic and Neartic, Afrotropical and Neotropical, Oriental and Australian regions (Segers, 2007). Despite countless records by Filinia longiseta in Brazilian inland waters (Garraffoni and Lourenço, 2012), there are few registers of this species in Mato Grosso state, local where this study was done. Four studies were conducted in the region, and from these, only Turner and Silva (1992) and Neves et al. (2003) reported Filinia longiseta.
Filinia longiseta has been registered in many types of Brazilian water bodies. In Amazon region, this species may be founded in varzea lakes (Koste and Robertson, 1983), in rivers (Koste and Hardy, 1984), in flooded lakes-river (Bozelli, 1992), natural and meander lakes (Keppeler, 2003; Keppeler and Hardy, 2004), as also in artificial reservoir (Espíndola et al., 2000).

Its widespread distribution has been also reported for other areas in Brazil: northeastern small lakes (Reid and Turner, 1988), marginal lakes of a river in the central region (Neves et al., 2003), southeastern coastal lagoons (Branco et al., 2002), streams, reservoirs and fish ponds from southeastern region (Sampaio et al., 2002; Lucinda et al., 2004; Sipaúba-Tavares et al., 2017), south lagoons of the river floodplain (Rossa and Bonecker, 2003), and riverine rotifers (Serafim-Júnior et al., 2016). For more details on the distribution of Filinia longiseta in Brazil, see Garraffoni and Lourenço (2012).

This interface may represent endemic nucleus for aquatic species and priority areas for aquatic conservation in Brazil (Brasil, 2007). Headwaters originated in this transition naturally flow towards the basins, most of the time forming ecological corridors for many aquatic species. These features may enable harbour a higher and endemic biodiversity (Leibowitz, 2003), especially in protected areas with a pristine condition.

The new record of rotiferan Filinia longiseta reinforce the importance to do surveying in headwaters of low-order streams located in the Cerrado drainage systems. Especially if these small watercourses are originally protected by a dense riparian vegetation. According to review done by Padovesi-Fonseca et al. (2015), under natural conditions, their waters are poor in nutrients, slightly acid and have low electric conductivity (up to $10 \mu \mathrm{S} / \mathrm{cm}$ ); and the water temperature remains between 17 and $20{ }^{\circ} \mathrm{C}$. Effects of environmental quality in headwaters of Cerrado domain have been evaluated and alterations derived by antropic impacts can influence on aquatic assemblages, as view by Machado et al. (2011).

The fist occurrence of Filinia longiseta presented by this study enhanced its geographic distribution in a transition area between the two major Brazilian biomes: Amazon and Cerrado. In this context, headwaters of the Amazon basin are situated in Cerrado, forming ecotone areas between the 
two biomes. The new record of rotiferan Filinia longiseta reinforce the importance to do surveying in headwaters of low-order streams located in the Cerrado drainage systems. The knowledge on habitat and ecological aspects of aquatic species may be enlarged due to new records of their geographic distribution in these areas of Brazil.

\section{Acknowledgements}

This work was supported by the CNPQ (National Council for Scientific and Technological Development) under grant (Research Network of Cerrado's Biota, RBPCerrado3. I am grateful to Mickael Pontes for technical assistance during field work.

\section{References}

BOZELLI, R.L., 1992. Composition of the zooplankton community of Batata and Mussurá Lakes and of the Trombetas River, State of Pará, Brazil. Amazoniana, vol. 12, pp. 239-261.

BRANCO, C.W.C., ROCHA, M.I.A., PINTO, G.F.S., GÔMARA, G.A. and FILLIPPO, R., 2002. Limnological features of Funil Reservoir (RJ, Brazil) and indicator properties of rotifers and cladocerans of the zooplankton community. Lakes and Reservoirs, vol. 7, no. 2, pp. 87-92. http://dx.doi.org/10.1046/j.1440-169X.2002.00177.x.

BRASIL. Ministério do Meio Ambiente - MMA, 2007. Priority actions for the conservation of biodiversity in the Cerrado and Pantanal - Brazil. Brasília: Brazilian Program of Biological Diversity, $540 \mathrm{p}$.

ESPÍNDOLA, E.L.G., MATSUMURA-TUNDISI, T., RIETZLER, A.C. and TUNDISI, J.G., 2000. Spatial heterogeneity of the Tucuruí Reservoir (State of Pará, Amazonia, Brazil) and the distribution of zooplanktonic species. Brazilian Journal of Biology $=$ Revista Brasileira de Biologia, vol. 60, no. 2, pp. 179-194. http://dx.doi. org/10.1590/S0034-71082000000200001. PMid:10959101.

GARRAFFONI, A.R.S. and LOURENÇO, A.P., 2012. Synthesis of Brazilian Rotifera: an updated list of species. Check List, vol. 8, no. 3, pp. 375-407. http://dx.doi.org/10.15560/8.3.375.

KEPPELER, E.C. and HARDY, E.R., 2004. Abundance and composition of Rotifera in an abandoned meander lake (Lago Amapá) in Rio Branco, Acre, Brazil. Revista Brasileira de Zoologia, vol. 21, no. 2, pp. 233-241. http://dx.doi.org/10.1590/ S0101-81752004000200011.

KEPPELER, E.C., 2003. Comparative study of the zooplankton composition of two lacustrine ecosystems in Southwestern Amazonia. Acta Scientiarum. Biological Sciences, vol. 25, pp. 467-477.

KOSTE, W., 1978. Rotatoria Die Rodertiere Mitteleuropas begründet von Max Voigt - Mongononta. Stuttgart: Borntraeger, 2 vol., $238 \mathrm{p}$.

KOSTE, W. and HARDY, E.R., 1984. Taxonomic studies and new distribution records of Rotifera (Phylum Aschelminthes) from Rio Jatapú and Uatumã, Amazonas, Brazil. Amazoniana, vol. 9, pp. 17-29.

KOSTE, W. and ROBERTSON, B., 1983. Taxonomic studies of the Rotifera (Phylum Aschelminthes) from a Central Amazonian varzea lake, Lago Camaleão (Ilha de Marchantaria, Rio Solimões, Amazonas, Brazil). Amazoniana, vol. 8, pp. 225-254.
LEIBOWITZ, S.G., 2003. Isolated wetlands and their functions: an ecological perspective. Wetlands, vol. 23, no. 3, pp. 517-531. http://dx.doi.org/10.1672/0277-5212(2003)023[0517:IWATFA ]2.0.CO;2.

LUCINDA, I., MORENO, I.H., MELÃO, M.G.G. and MATSUMURATUNDISI, T., 2004. Rotifers in freshwater habitats in the upper Tietê river basin, São Paulo State, Brazil. Acta Limnologica Brasiliensia, vol. 16, pp. 203-224.

MACHADO, N.G., VENTICINQUE, E.M. and PENHA, J., 2011. Effect of environmental quality and mesohabitat structure on a Biotic Integrity Index based on fish assemblages of cerrado streams from Rio Cuiabá basin, Brazil. Brazilian Journal of Biology = Revista Brasileira de Biologia, vol. 71, no. 3, pp. 577-586. http:// dx.doi.org/10.1590/S1519-69842011000400002. PMid:21881781.

NEVES, I.F., ROCHA, O., ROCHE, K.F. and PINTO, A.A., 2003. Zooplankton community structure of two marginal lakes of the River Cuiabá (Mato Grosso, Brazil) with analysis of Rotifera and Cladocera diversity. Brazilian Journal of Biology $=$ Revista Brasileira de Biologia, vol. 63, no. 2, pp. 329-343. http://dx.doi. org/10.1590/S1519-69842003000200018. PMid:14509855.

PADOVESI-FONSECA, C., MARTINS-SILVA, M.J. and PUPPINGONÇALVES, C.T., 2015. Cerrado's areas as a reference analysis for aquatic conservation in Brazil. Biodiversity Journal, vol. 6, no. 4 , pp. $805-816$.

REID, J.W. and TURNER, P.N., 1988. Planktonic Rotifera, Copepoda and Cladocera from lagos Açú and Viana, State of Maranhão, Brazil. Brazilian Journal of Biology $=$ Revista Brasileira de Biologia, vol. 48, pp. 485-495.

ROSSA, D.C. and BONECKER, C.C., 2003. Abundance of planktonic and non-planktonic rotifers in lagoons of the Upper Paraná River floodplain. Amazoniana, vol. 17, pp. 567-581.

SAMPAIO, E.V., ROCHA, O., MATSUMURA-TUNDISI, T. and TUNDISI, J.G., 2002. Composition and abundance of zooplankton in the limnetic zone of seven reservoirs of the Paranapanema River. Brazilian Journal of Biology $=$ Revista Brasileira de Biologia, vol. 62, no. 3, pp. 525-545. http://dx.doi.org/10.1590/ S1519-69842002000300018. PMid:12530191.

SEGERS, H., 2007. Annotated checklist of the rotifers (Phylum Rotifera), with notes on nomenclature, taxonomy and distribution. Zootaxa, vol. 1564, no. 1, pp. 1-104. http://dx.doi.org/10.11646/ zootaxa.1564.1.1.

SERAFIM-JÚNIOR, M., LANSAC-TÔHA, F.A., LOPES, R.M. and PERBICHE-NEVES, G., 2016. Continuity effects on rotifers and microcrustaceans caused by the construction of a downstream reservoir in a cascade series (Iguaçu River, Brazil). Brazilian Journal of Biology $=$ Revista Brasileira de Biologia, vol. 76, no. 2, pp. 279-291. http://dx.doi.org/10.1590/1519-6984.00314. PMid:26983084.

SIPAÚBA-TAVARES, L.H., DURIGAN, P.A., BERCHIELLIMORAIS, F.A. and MILLAN, R.N., 2017. Influence of inlet water on the biotic and abiotic variables in a fish pond. Brazilian Journal of Biology = Revista Brasileira de Biologia, vol. 77, no. 2, pp. 277-283. http://dx.doi.org/10.1590/1519-6984.12315. PMid:27533726.

TURNER, P.N. and SILVA, C., 1992. Littoral rotifers from the State of Mato Grosso, Brazil. Studies on Neotropical Fauna and Environment, vol. 27, no. 4, pp. 227-241. http://dx.doi. org/10.1080/01650529209360881. 